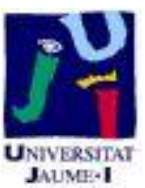

Título artículo / Títol article: Philosophical Perspectives on Caring Citizenship
Autores / Autors
Comins Mingol, Irene

Revista:

Peace Review: A Journal of Social Justice, 2013, Volume 25, Issue 3

Versión / Versió:

Cita bibliográfica / Cita bibliogràfica (ISO 690):
Post-print del autor

MINGOL, Irene Comins. Philosophical Perspectives on Caring Citizenship.Peace Review: A Journal of Social Justice, 2013, vol. 25, no 3. 


\section{Philosophical Perspectives on Caring Citizenship}

Irene Comins Mingol

Our globalized world has two main characteristics: firstly, the shrinking of the sovereignty of the nation state and, secondly, the imposition of economic discourse over political discourse. In response to this situation, various authors have suggested alternatives in the form of two complimentary lines of study: on one hand, the development of global political and democratic institutions and on the other, the consolidation of a participatory citizenship for revitalizing democracy. My analysis lies in this second line, where I specifically focus on the contributions provided by the feminist paradigm of a "philosophy of care.” I argue that from this ethics of care, we can learn to revitalize and sustain citizenship praxis.

Historically, and in different cultures, women have been assigned a restrictive role of caregivers as a way of relegating them to the private sphere. This subjugation still continues today. It is the root of the feminization of poverty in impoverished countries and of the double working day and the glass ceiling in so-called developed countries. In Peace Studies, an important line of research is to bring to light and denounce the unequal distribution of caring responsibilities, the source of an unequal and unjust gender-sex system.

However, we cannot ignore the ways in which the praxis of care triggers at the same time the development of moral values that are cornerstones for practices of an awakened citizenship. The basic moral concepts that sustain the practices of care, such as commitment, responsibility, empathy or interconnection, are essential for building a participatory citizenship, a healthy and vibrant civil society. In her 1982 work, In a Different Voice, Carol Gilligan demonstrates how socialization and the praxis of care develop a specific moral voice in women. This concept has come to be known as the ethics of care (or of responsibility) as distinct from the ethics of justice (or of rights). The voices and experiences of women enabled Gilligan to challenge Kohlberg's traditional conception of moral development theory based on an ethics of justice. Gilligan claims that Kohlberg's theory of moral development is biased because it ignores the reality of the experiences of women. Based on a study of 84 male subjects over a period of more than twenty years, Kohlberg designed six stages to describe the development of moral judgment. When Gilligan extended the study to include girls and 
women, she found a different moral voice, which led to the theory of an ethics of care. The origin of this different moral voice lies in the clear-cut division of responsibilities between men and women.

Implicit in the socialization and practice of care is the development of certain moral values and skills such as empathy, patience, perseverance, responsibility, commitment, listening and tenderness. These competencies are prerequisites for the practice of care, but also for building a culture of peace. For this reason the peace scholar Betty Reardon states that "a culture of peace would be a culture of caring." In addition to the importance of care in developing these moral values, and aside from the fact that caring activities are vital for satisfying basic needs, caring helps to develop two fundamental skills that are not exclusively limited to the private sphere and include the public sphere as well: skills for the peaceful transformation of conflict and skills for social and civic commitment.

These socialized caring practices (in diverse social, cultural, economic and political contexts) influence women in their commitment to the well-being of society in general and not only to the immediate family. This explains the predominance of women in social and volunteer movements. For example, in Spain, women account for more than $75 \%$ of volunteers, and worldwide, they have a majority presence in environmental and pacifist movements. Despite the difficulties women face in participating in formal politics, their participation in informal politics and civil society is of unquestionable importance. One example is the Women in Black movement that began in 1988 when a group of Israeli women held a vigil in a Jerusalem square with placards reading, "Stop the Occupation." Women in Black in Belgrade followed the Israeli Women in Black. Gradually, an international Women in Black network spread under the slogan, Let us banish war from history. Other groups are less well known but equally compelling. This is the case of Bat Shalom in Israel-Palestine or Hands Across the Divide in Cyprus. Both groups share a common interest in bringing separated and divided communities together. In Latin America, movements of women against impunity and for the recovery of truth and justice have a long history. The Argentine Mothers and Grandmothers of the Plaza de Mayo, the National Coordination of Widows of Guatemala or the Committee of Mothers of the Disappeared in El Salvador are just a few examples. There are local movements like the Chipko movement in India and 
international movements such as the Women's International League for Peace and Freedom, WILPF. Through these different movements, women have broken the culture of silence, exclusion and systematic discrimination.

Women have been at the forefront of an empowering shift in perspective: from passive victims to actors and agents of change, from the private to the public and political domain, from the local to the global sphere. The slogan underlying this transforming current could be: "We are not victims; we have reframed ourselves as political actors.”

Hence, although decision-making politics remains under male hegemony, women are drivers of change for building peace through social movements and informal politics. For this reason, denouncing women's subordination has become an important research line in Peace Studies. Another essential line of research is to increase the visibility of women's contributions to building peace in different spheres of civil society. By focusing solely on the former, we may end up victimizing women, thereby ignoring the many capacities and contributions of women as agents of change. Indeed, the victimization of women, conceived as passive subjects, mere recipients, has at times been used to justify their exclusion from the very negotiating tables where policies for their development are being designed. This victimization does not reflect the potential of women as agents of peace and ultimately feeds the vicious cycle of violence and unequal distribution of power. It is therefore essential not only to denounce the subordination of women and all types of direct, structural and cultural violence of which they are victims, but also to make visible and highlight the legacy of women in sustaining life and building peace throughout history and in all cultures. This legacy is a school for learning peace. Only by reaching a balance between these two lines of research can we contribute to real emancipation, not only for women but also for the whole of humanity.

Various authors have analyzed the importance of motherhood as a key element in the participation of women as active civil society agents for peace. Sara Ruddick is one of these authors. Her concept of maternal thinking alludes to the commitment of women to the values necessary to sustain and care for children and how maternal thinking can nourish and contribute to building a politics of peace. However, in my 
view, and an opinion shared by other authors, it is not motherhood that is the epicenter of the political and social involvement of women, but rather a wider concept of care and an ethics of care. It is this ethics of care that leads many women (not necessarily mothers) to participate in environmental, pacifist and democratization movements across the world. The vast majority of women in every country in the world are socialized in the value and praxis of care-caring for children, the home, the elderly or the sick. However, not all women experience motherhood during their lives. At the same time, men can also be socialized in the value of caring, a value that can be acquired without the biological experience of motherhood. It would therefore be more accurate to say that it is the learnings of caring in general (of which maternal thinking would only be an expression) that drive many women to move from the private sphere to public participation in different areas of civil society.

Why is the ethics of care a key element in participatory citizenship? For Gilligan, the moral development of women based on the praxis and socialization of caring is different from the ethics of justice in two fundamental ways. Firstly, the moral judgment of women is more contextual, more immersed in the details of relationships. Secondly, women are more likely to adopt the point of view of the particular other. The ethics of care, therefore, highlights the responsibilities that arise from the relationships and interpersonal links between human beings and the importance of attending to specific needs, particularly of the most vulnerable. In this process, the activation of empathy and caring is essential. From this outward-looking attitude to the world, the ethics of care becomes the catalyst and source of inspiration for citizen participation.

Care as a value can transform the ethical concepts on which citizenship is practiced, as Selma Sevenhuijsen, Peta Bowden and Ruth Lister point out in their defense of the importance of caring in reshaping the concept of citizenship. We now turn to three contributions on caring, which I believe are fundamental to shaping the new paradigm of citizenship: the conception of a relational subject, the importance of motivation for participatory citizenship and citizenship as action (relation-motivationaction).

The core focus of moral action in the ethic of care in which women are socialized is to sustain interpersonal relationships and prevent them from breaking up. In contrast, the core focus of moral action in the ethics of justice is to comply with 
abstract universal principles, if necessary at the expense of interpersonal relationships. It can even justify war and the destruction of human lives, considered as mere collateral effects, under the banner of freedom, equality or any other universal principle. Thus, from the ethics of care perspective, the subject is intrinsically relational, prioritizing in its moral action the sustaining of life and interconnection with others. Annette Baier has used the Marxist concept of alienation to compare Gilligan's critique with individual autonomy and rootlessness. Working in the capitalist enterprise alienates workers by separating them from the product of their labors. The ethics of justice morally alienates individuals by separating them from their main source of morality: interconnection with others. According to Baier, some of the effects of this lack of interconnection are loneliness, apathy to participate in political processes or the meaninglessness of life. Implicit in the moral maturity of the ethics of care is a more committed, responsible and interconnected citizenship. Although one of the great achievements of Western modernity was the discovery of autonomy, this achievement has degenerated into excessive individualism in so called developed societies, an individualism that inflates individual rights, ignores duties and involves the loss of a sense of belonging to a community. The ethics of care has generated a critique of this abstract individualism, an individualism that undervalues the role of social relationships in building the identity and nature of human beings. The subjects of abstract individualism are presented as utilitarian maximizers who rationally pursue their own interests and benefits. In contrast to this individualist abstract conception of the ego and the human community, the ethics of care puts forward a conception of the ego as inherently social. Conflict and competition are no longer considered to be basic human relations, but rather are replaced by alternative visions of the foundation of human society derived from a devotion to caring and attention.

The traditional civic values of justice, equality and freedom constitute a necessary, yet insufficient, minimum to achieve participatory democracy. The task that remains is to reconstruct the paradigm of a democratic citizenship through the development of a new language that can incorporate relational values. The concept of the human being as inherent to the ethics of care differs from the concept of unilateral individualism of much political theory. Interrelation and interdependence are central concepts in an ethics of care. The thinking behind the ethics of care is that people need each other to achieve a quality of life, and they can only develop as individuals through caring relationships with others. In her 2003 published work, “The Place of Care: The 
Relevance of the Feminist Ethic of Care for Social Policy," Selma Sevenhuijsen uses the term relational autonomy to refer to this phenomenon. From the ethics of care, relationships and interdependence of people form the fundamental network on which we base our actions and position ourselves in the world.

If, as described above, the first contribution of care in building a new citizenship is based on the relational subject, the second contribution is related to the subject's motivation to participate in public life. Participation requires motivation. An important motivating factor is the concern for the well-being of other people and the environment as well as the recognition that we have the capacity to be agents of change. The marginalization and restriction of the value of care to the private sphere has had harmful consequences for the public sphere. The lack of involvement, commitment, motivation, and sense of responsibility for our immediate environment are the most obvious symptoms of this phenomenon. More than half a century ago, Erich Fromm noted the "insignificance and powerlessness of the individual" as a danger in Western society. Hence, it is of utmost importance to reclaim care for rebuilding the foundations of a participative citizenship. Through caring, people feel significant, important and necessary. They also realize that they have a certain power to change reality. The individual is more likely to live a good and happy life when he/she participates responsibly in the social structures of his/her society. Democracy, therefore, fulfills two of its dimensions: the instrumental dimension, as the method that allows disputes to be resolved peacefully and requires that governments satisfy the needs of its citizens; and the substantial dimension, in that the political participation of citizens is a human activity that is intrinsically inseparable from the development of human qualities.

Finally, and related to this, caring contributes to defining the practice of citizenship as action. Democracies cannot be reduced to their legal dimension or to a game of majorities and minorities. The alternative is to reconstruct a direct democracy with a participative civil society that has a wider range of options for action. Specifically, according to Joan Tronto, Ruth Lister and Selma Sevenhuijsen, caring as a social process and an active civil society practice develops in three phases that can be summarized as follows: being sensitive and noticing the social needs of care; assuming the responsibility and potential to be an agent of change; and carrying out pertinent actions or, in other words, engaging in care-giving. With this structure, caring serves as a basis for the political achievement of a better society. In this vein, Tronto proposes a simple definition of citizenship: the process in which citizens commit to and involve 
themselves in processes of care. This definition of citizenship can transform the way in which we think of public and private life and how we understand political participation. It is therefore important to make available space and time for the practices of a caring and responsible citizenship: practices in which people can show themselves as caregivers and/or recipients of care, in dialogue with each other, concerned for their own well-being, that of others and of the environment. This paves the way for new forms of democratic action that incorporate caring as a guiding essence, transforming caring into a practice of participative democratic politics.

Many authors now speak of a new politics of care, referring to two complementary realities. The first is the growing prominence that a politics of care is gaining ground in the political sphere. Examples of this include the Dependency Law in Spain or government efforts to address the work-life balance in different countries. This prominence has been achieved as a result of the demands of feminists and other social movements. Yet, we must continue with these demands now that the economic crisis and neo-liberalism are challenging and threatening these policies. As argued in this work, the second of these realities is the demand to incorporate the values of an ethics of care into citizen participation, in what has come to be known as a caring citizenship. From these two realities, a politics of care refers to the way in which caring moves out of the private sphere and into the public sphere in a transforming and enriching process, both at the level of public politics and its priorities and in building a new paradigm of citizenship.

Recently, in an article entitled, “Times of Crisis - Times of Caring,” Leonardo Boff states, "today, given the general crisis, [...] caring becomes essential for preserving [...] the continuity of our species and our civilization.” In a period of crisis that requires reformulating paradigms, caring can play a pivotal role in a radical critique and a reformulation of democracy. With its two attributes of increasing our responsibility and our sense of interconnection, caring is the key to a participative democratic system. Above all, it is essential to a citizenry that is not only revealed and concerned about its own particular interests, but is also aware of its spheres of responsibility and its numerous possibilities for daily civic action. Whether individual or collective, such a citizenry is necessary for promoting the well-being of the most vulnerable and for sustaining the environment. 
Having analyzed the contributions caring makes to building participative citizenship, we realize there is a need to recover care in its various senses. Firstly, it is essential to "de-gender" it, to reclaim caring as a value for everybody and not as a gender role. As Elise Boulding points out, highlighting the importance of care is not essentialist, as it does not propose that women are biologically predisposed to caring, citizen participation and working towards peace. As Boulding notes in her book Cultures of Peace: The Hidden Side of History: "women's knowledge and experience worlds have equipped them to function creatively as problem solvers and peacemakers in ways that men have not been equipped by their knowledge and experience worlds.” This, obviously, can change. A greater sharing between the worlds of experiences of men and women will mark an important step in human development. Secondly, I refer to the need to recover care because it is a value that has fallen into disuse with younger generations, in a world in which speed and economic interests put a strain on caring relationships. Finally, recovering care, also involves its deconstruction in order to reconstruct it. Not everything in the practice of care is positive. For instance, due to continued attitudes of sacrifice and/or paternalist attitudes and structures, excessive care can result, in the first case, in overturning the caring person's freedom and, in the second, in restraining the empowerment processes of the person being cared for. We must find a point where the ethics of care and the ethics of justice can meet, so that care is balanced with justice criteria in an interdependent relationship. In this way, the traditional dichotomy assumed between them is transformed into common and complementary reference models.

All of the above should lead us to a normative reconstruction of caring as a human competence for peace and as the mainstay of a new paradigm of a caring citizenship.

\section{Recommended Readings}

Antrobus, Peggy. 2004. The Global Women's Movement: Issues and Strategies for the New Century. London: Zed.

Bowden, Peta. 1997. Caring: Gender-Sensitive Ethics. London: Routledge.

Cancian, Francesca M. and Stacey J. Oliker. 2000. Caring and Gender. Oxford: Rowman \& Littlefield Publishers.

Fromm, Erich. 1941. Escape from Freedom. New York: Rinehart and Company. Gilligan, Carol. 1982. In a Different Voice. Harvard: Harvard University Press. 
Hankivsky, Olena. 2004. Social Policy and the Ethic of Care. Vancouver: University of British Columbia Press.

Hawkesworth, M.E. 2006. Globalization and feminist activism. London: Rowman \& Littlefield.

Held, Virginia. 1995. Justice and Care: Essential Readings in Feminist Ethics. Colorado: Westview Press.

Larrabee, Mary Jeanne. 1993. An Ethic of Care. London: Routledge.

Lister, Ruth.1997. Citizenship, Feminist Perspectives. London: Macmillan Press.

Magallón Portolés, Carmen. 2012. Contar en el Mundo. Una mirada sobre las relaciones internacionales desde las vidas de las mujeres. Madrid: Horas y Horas.

Martínez Guzmán, Vicent. 2006. "Negative and Positive Peace.” in Geeraerts, G., Pauwels, N. and Remacle, E. (eds.) Dimensions of Peace and Security: A reader. Brussels: Peter Lang Publishers.

Postigo Asenjo, Marta. 2007. Género y ciudadanía. El discurso feminista en la ciudadanía liberal. Málaga: Universidad de Málaga.

Reardon, Betty. 2001. Education for a Culture of Peace in a Gender Perspective. Paris: UNESCO.

Robinson, Fiona. 1999. Globalizing Care. Ethics, Feminist Theory and International Relations. Oxford: Westview Press.

Ruddick, Sara. 1997. Maternal Thinking. Towards a Politics of Peace. New York: Women's Press.

Sevenhuijsen, Selma. 2003. "The place of care. The relevance of the feminist ethic of care for social policy,” Feminist Theory: 4 (2), 179-197.

Sevenhuijsen, Selma. 1998. Citizenship and the ethics of care: Feminist considerations on justice, morality and politics. London: Routledge.

Smith, Jackie. 2008. Social Movements for Global Democracy. Baltimore: The John Hopkins University Press.

Tickner, J. Ann. 2004. "Feminist responses to international security studies," Peace Review: A Journal of Social Justice: 16 (1), 43-48.

Tronto, Joan C. 1993. Moral Boundaries: A Political Argument for an Ethic of Care. London: Routledge.

Tronto, Joan C. 1998. "What Can Feminist Learn about Morality from Caring?” in Sterba, James P. (ed.), Ethics: The Big Questions. Oxford: Blackwell.

Woodward, Alison. 2004. "Building Velvet Triangles: Gender and Informal Governance." in Simona Piattoni and Thomas Christiansen (eds.), Informal Governance and the European Union. London: Edward Elgar.

Short bio:

Dr. Irene Comins Mingol is full-time lecturer at the Department of Philosophy and Sociology of the Universitat Jaume I, Castellón (Spain). She is also a research member of the UNESCO Chair of Philosophy for Peace and the IUDESP. Since 2009 she is the Co-Director of the International Master in Peace, Conflict and Development Studies at the same University. She regularly publishes about Philosophy for Peace, Philosophy of Language, Peace Education, Anthropology for Peace, and Gender Issues. She is also member of different international associations related to peace and gender studies like WILFP Women's Internacional League for Peace and Freedom. E-mail: cominsi@uji.es 